\title{
Does water and sanitation effects on children's physical development? Evidence from Indonesia Family life Survey (IFLS) 2014
}

\author{
Israul Hasanah ${ }^{1, *}$ and Hera Susanti ${ }^{1}$ \\ ${ }^{1}$ Department of Economics, Universitas Indonesia, 16424, Depok, Indonesia
}

\begin{abstract}
Chronic malnutrition (Stunting) is one of the most serious health problems in Indonesia. Almost 8.9 million or $37.2 \%$ of all Indonesian children under 5 were stunted in 2013. The negative impact as a result of stunting in early of life associated with high mortality, decrease cognitive development, poor school performance, and reduce productivity as adults. Stunting associated with long-term nutrition intake and the burden of diseases. Around $56 \%$ of malnutrition is associated with inadequate water, sanitation and hygiene. Conversely Investing to increase safe drinking water and proper sanitation provides many benefits for eliminating stunting. This paper analyzes how a poor water and sanitation affect a child's stunting in Indonesia. Using logistic regression methods and large-scale data from the Indonesia Family Life Survey (IFLS) 2014, we selected 2835 children aged 0-5 years old in 2014 who considered stunting. The study finds that they are significantly associated between proper sanitation and number of stunting under 5. Children who live in a household with lack sanitation have the possibility of stunted 0.645 times higher than children living in the household with proper sanitation. While children living in unprotected water more likely to being stunted 0.874 times but statistically significant.
\end{abstract}

\section{Introduction}

Stunting in early of life is a persistent phenomenon among children under age 5 in Indonesia. More than eight million or $37.2 \%$ of all Indonesia children under 5 suffered from stunting [2]. Indonesia ranks fifth in term of a country with stunted children in the world which more than $30 \%$ (Fig. 1). Malnutrition cause of the $45 \%$ or over 3.1 million annual deaths of children under 5. Chronic malnutrition problem caused by long-term insufficient nutrient intake and frequency of infection. Its have an irreversible negative impact on cognitive and non-cognitive development, lower attending at school and school performance, low height during adulthood, increase the risk of chronic disease as an adult, and reduced economic productivity in adults $[3,10,11,14]$. A mother who has short stature most likely has smaller babies and experiencing with a pregnancy complication [23]. Recent studies have also found that stunting in early life effects on emotional development

\footnotetext{
*Corresponding author: israulhasanah8@gmail.com
} 
such as increasing apathy, decreasing activity, and decreasing interest in their environment [9]. Stunting decreases adult income by 5-53\% [12]. In Asia and Africa, the high prevalence of stunting causes a loss of $11 \%$ of the total Gross National Product (GNP) [22]. Adults, who were stunted under age 5 experiencing with lower income of $22 \%$ compared to an adult who was not stunted [11]. In the economic aspect, another study providing that an investment one dollar to eliminating stunting will generate economic returns of the US \$17.9-the US \$18.4 [12].

Stunting is a complex problem caused by various conceptual frameworks, stunting is a form of nutrition problems [1, 23]. Intergenerational characteristics, including parental education, parental height and maternal age at delivery $[8,10,15,24]$. There have been quite a lot of studies about child stunting in Indonesia, yet based on the author's knowledge, none of it discusses the relationship between water and sanitation and child stunting in Indonesia. Environmental factors, especially water and sanitation have a strong influence on the incidence of stunting [20,24]. Environmental problems such as an open toilet become environmental factors that are closely related to the incidence of stunting [27]. This situation can be explained given the quality and quantity of water and sanitation associated with the development of diarrhea diseases and various infectious diseases that can inhibit the growth of children. Several previous studies as also have shown a link between environmental conditions and health conditions, including water, sanitation, and hygiene (WASH). WASH provides a direct impact on the development of various infectious diseases, especially diarrhea that plays an important role to encourage the occurrence of malnutrition. Estimated 663 million people worldwide have no access to clean water, 1.9 billion people still consume contaminated water and 2 billion people do not have access to safe sanitation [26]. Estimated 1.5 million child deaths in the world are affected by unclean water, inadequate hygiene, and lack of adequate sanitation [5]. Studies show that children, especially girls, are more likely to stay in school and attend lessons when there are clean water and sanitation.

Poor conditions of WASH are associated with $6.6 \%$ of the global burden of disease and disability, and 2.4 million deaths annually due to diarrhea [17]. The study by Hutton and Haller for the WHO (2004) found that a US\$ 1 investment in water and sanitation in developing countries yielded returns of US\$5 - US\$28 [13]. Most of the benefit consisted of time saved from gathering clean water and securing the private place to defecate, but also decreases mortality and morbidity and economic saving from avoiding diarrhea disease, both direct of healthcare expenditure and indirect effect of decrease saving from unable to work. Water is associated with the loss of school days as much as 443 million and causes a lack of cognitive abilities. The burden of disease due to water and sanitation resulted in a loss of 60 million disability-adjusted life years (DALY). According to WHO/UNICEF (2014), unsafe water and sanitation affect nutritional status in children through 3 things, diarrhea diseases, parasitic infections and Environmental Enteropathy (EE) $[26]$.

\section{Method}

This study used data from the Indonesia Family Leave Survey (IFLS) wave 5. Indonesia Family Life Survey (IFLS) is a continuing longitudinal socioeconomic and health survey, representing about 83 percent of the Indonesian population living in 13 provinces. The unit analysis of IFLS data is individual, families, household, the community in the society they live in, and the facilities of health and education they use. Regression models for binary response variable are divided into linear probability model (LPM), a logistic regression model, and probit model. This study uses the logistic regression model to estimate the effect of water and sanitation on the probability of children being stunted. 


\section{Discussion}

In developing countries, including Indonesia, socioeconomic conditions become one of the causes of growth failure in children The relationship between infectious diseases and stunting that occur in many developing countries one of them caused by lack of food, nutrition, and health care. The importance of drinking water, proper sanitation, and hygiene have long been recognized by public health. Investing in WASH is wide as essential for improving health in early childhood. Diseases that occur in early childhood often associated with poor sanitation and hygiene and limited access to drinking water. The table below shows the effects of water, sanitation and other variables to stunting using logistic regression. This study was initially designed to evaluate the influences of environmental characteristic especially water and sanitation on chronic malnutrition or stunting among children 0-5 years in Indonesia. However, based on table 2, after controlling using child characteristic and household characteristic, intergenerational characteristic, including parental height, mother years of schooling and age of giving birth has a significant relationship with the possibility of the child being stunting. Child height is an accumulative result from the interaction between environmental and intergenerational or genetic characteristic over the growing period.

The Previous study shows that the association between parental height, especially maternal height on child stunting and human capital development $[4,18]$. This is because of short women associated with offspring birth size, maternal physical constraints on offspring growth in utero [16]. Column (1) and (3) showed that maternal education has a positive and significant at $\alpha=1 \%$ level. This means that the higher the mother's education the value of HAZ will be higher. An increase in one year of maternal education will decrease the tendency to be stunted by 0.971 times, but father's education has no significant effect to increase the likelihood of being stunting on their children. Moreover, theories suggesting that more years of parental education induce to have higher earnings and increased family incomes, which provide enable to provide child care [7]. In theory, there is various studies show the effect of maternal age at delivering might effect's on child's outcome. Some study of them offers a negative effect between maternal age at birth and their children's outcomes if mothers do not give birth at the range of age. $\square$

Based on table 1, sanitation significantly decreases the tendency of children's to become stunted. This means that there is a difference between the health status of children under five due to differences in the sanitation used in the household. Column (5), explains that based on the odds ratio, using protected sanitation reduces the likelihood of being stunted by 0.684 times compared to children with unprotected sanitation and statistically significant. In terms of water, based on the column (5), using protected water reduced the likelihood of being stunted by 0.874 times compared to children with unprotected water but not statistically significant. Furthermore, as many as 413 toddlers who experienced stunting came from families with unprotected water sources and 204 other children came from families with protected water sources. Based on the type of toilet, 333 stunted toddlers used decent toilets and 262 children came from families with inadequate toilets. 
Table 1. Logistic regression.

\begin{tabular}{|c|c|c|c|c|c|c|}
\hline $\begin{array}{l}\text { Independent } \\
\text { Variables }\end{array}$ & $\begin{array}{c}\text { Model (1) } \\
\text { Logistic } \\
\text { Estimation }\end{array}$ & $\begin{array}{l}\text { Model (2) } \\
\text { Logistic } \\
\text { Estimation }\end{array}$ & $\begin{array}{l}\text { Model (3) } \\
\text { Logistic } \\
\text { Estimation }\end{array}$ & $\begin{array}{c}\text { Model (4) } \\
\text { Logistic } \\
\text { Estimation }\end{array}$ & $\begin{array}{c}\text { Model (5) } \\
\text { Logistic } \\
\text { Estimation }\end{array}$ & $\begin{array}{l}\text { Odd } \\
\text { Ratio }\end{array}$ \\
\hline $\begin{array}{l}\text { Stunting } \\
\text { Mother }\end{array}$ & $\begin{array}{c}.431 * * * \\
(.095)\end{array}$ & & $\begin{array}{c}.415 * * * \\
(.095)\end{array}$ & $\begin{array}{c}.384 * * * \\
(.103)\end{array}$ & $\begin{array}{c}.385 * * * \\
(.104)\end{array}$ & $\begin{array}{l}1.470 \\
(.157)\end{array}$ \\
\hline $\begin{array}{l}\text { Stunting } \\
\text { Father }\end{array}$ & $\begin{array}{c}.283^{* * *} * \\
(.095)\end{array}$ & & $\begin{array}{c}.285^{* * *} \\
(.096)\end{array}$ & $\begin{array}{c}.344 * * * \\
(.104)\end{array}$ & $\begin{array}{c}.325 * * * \\
(.105)\end{array}$ & $\begin{array}{l}1.384 \\
(.150)\end{array}$ \\
\hline $\begin{array}{l}\text { Mother } \\
\text { Years of } \\
\text { Schooling }\end{array}$ & $\begin{array}{c}-.036 * * * \\
(.013)\end{array}$ & & $\begin{array}{c}-.030^{* *} \\
(.013)\end{array}$ & $\begin{array}{c}-.037 * * * \\
(.014)\end{array}$ & $\begin{array}{c}-.034 * * \\
(.013)\end{array}$ & $\begin{array}{c}.966 \\
(.014)\end{array}$ \\
\hline $\begin{array}{l}\text { Father } \\
\text { Years of } \\
\text { Schooling }\end{array}$ & $\begin{array}{l}-.003 \\
(.012)\end{array}$ & & $\begin{array}{c}.005 \\
(.013)\end{array}$ & $\begin{array}{c}.001 \\
(.013)\end{array}$ & $\begin{array}{r}.007 \\
(.013)\end{array}$ & $\begin{array}{l}1.007 \\
(.014)\end{array}$ \\
\hline $\begin{array}{l}\text { Age of } \\
\text { Giving } \\
\text { Birth }\end{array}$ & $\begin{array}{l}.005 \\
(.008)\end{array}$ & & $\begin{array}{l}.010 \\
(.008)\end{array}$ & $\begin{array}{c}-.031 * * * \\
(.010)\end{array}$ & $\begin{array}{c}-.029 * * * \\
(.010)\end{array}$ & $\begin{array}{c}.970 \\
(.105)\end{array}$ \\
\hline Water & & $\begin{array}{c}-.202 * * \\
(.100)\end{array}$ & $\begin{array}{c}-.189 * * \\
(.102)\end{array}$ & $\begin{array}{l}-.192^{*} \\
(.113)\end{array}$ & $\begin{array}{l}-.134 \\
(.116)\end{array}$ & $\begin{array}{c}.874 \\
(.101)\end{array}$ \\
\hline Sanitation & & $\begin{array}{c}-.520 * * * \\
(.112) \\
\end{array}$ & $\begin{array}{c}.455^{* * *} * \\
(.118) \\
\end{array}$ & $\begin{array}{c}-.465 * * * \\
(.136) \\
\end{array}$ & $\begin{array}{c}.437 * * * \\
(.137) \\
\end{array}$ & $\begin{array}{c}.645 \\
(.086) \\
\end{array}$ \\
\hline Sex & & & & $\begin{array}{c}.293 * * * \\
(.104)\end{array}$ & $\begin{array}{c}.298 * * * \\
(.104)\end{array}$ & $\begin{array}{l}1.347 \\
(.143)\end{array}$ \\
\hline Age & & & & $\begin{array}{c}-.723 * * * \\
(.045) \\
\end{array}$ & $\begin{array}{c}.723 * * * \\
(.045) \\
\end{array}$ & $\begin{array}{c}.485 \\
(.018) \\
\end{array}$ \\
\hline $\begin{array}{l}\text { Birth } \\
\text { weight }\end{array}$ & & & & $\begin{array}{c}.413^{* *} \\
(.204) \\
\end{array}$ & $\begin{array}{l}-.388^{*} \\
(.206)\end{array}$ & $\begin{array}{c}.678 \\
(.132) \\
\end{array}$ \\
\hline Birth Order & & & & $\begin{array}{c}.232 * * * \\
(.063)\end{array}$ & $\begin{array}{l}.159^{* *} \\
(.081) \\
\end{array}$ & $\begin{array}{l}1.172 \\
(.099) \\
\end{array}$ \\
\hline $\begin{array}{l}\text { Number of } \\
\text { Children }\end{array}$ & & & & & $\begin{array}{c}.059 \\
(.057) \\
\end{array}$ & $\begin{array}{l}1.060 \\
(.603)\end{array}$ \\
\hline Log_PCE & & & & & $\begin{array}{l}-.179^{*} \\
(.100)\end{array}$ & $\begin{array}{c}.835 \\
(.087)\end{array}$ \\
\hline Urban & & & & & $\begin{array}{c}-.173 \\
(.108)\end{array}$ & $\begin{array}{l}.840 \\
(.093\end{array}$ \\
\hline Constanta & $\begin{array}{l}-1.455 \\
(.265)\end{array}$ & $\begin{array}{c}-.826 * * * \\
(.104)\end{array}$ & $\begin{array}{c}-1.242 * * * \\
(.264)\end{array}$ & $\begin{array}{c}1.255^{* * *} \\
(.368)\end{array}$ & $\begin{array}{c}3.408^{* * * *} \\
(1.383)\end{array}$ & $\begin{array}{l}30.208 \\
43.530 \\
\end{array}$ \\
\hline Obs & 2835 & 2835 & 2835 & 2835 & 2835 & 2835 \\
\hline Prob $>$ chi2 & 0.0000 & 0.0000 & 0.0000 & 0.0000 & 0.0000 & 0.0000 \\
\hline Pseudo R2 & 0.0179 & 0.0107 & 0.0255 & 0.2080 & 0.2108 & 0.2108 \\
\hline
\end{tabular}

Stunting caused Long-term malnutrition to occur from the pregnancy until the 2 years of life. Lack of drinking water and poor sanitation could cause lack of mineral or lead to ill health women during pregnancy and the development of the fetus becomes imperfect. Infection during pregnancy caused by poor sanitation and hygiene as associated with high risk of maternal death. Furthermore, contaminated water is associated with the development of malaria, diseases which are also harmful to health while pregnant and childhood diseases. Clean water is one of the basic needs of humans to meet healthy living standards. People who are satisfied with the need for clean water will avoid diseases that spread through water and have a quality life. Limited access to the clean water and poor 
sanitation either in individual sanitation or public sanitation associated with poor nutritional outcomes from different pathway including diarrhea, HIV, and malaria.

\section{Conclusion}

Environmental characteristics, including water quality and sanitation have a strong relationship with stunting. Poor water quality and sanitation lead to the development of various kinds of disease, causing child grow to be not optimal. Based on the results of logistic regression analysis, in this study, there is no significant relationship between the types of a water source to the stunting. However, the type of sanitation significantly decreases the possibility of children being stunting and is consistent at $\alpha=1 \%$. Nutrition early in life is an important indicator in the framework of human resource development. Providing intervention in the context of improving nutritional status. Through provide the quality of the environment, especially the improvement of water quality and sanitation. Poor water quality and sanitation are one of the causes of the development of various forms of diseases such as diarrhea and other infectious diseases. The government's role in improving water quality and sanitation will have a major impact on health, especially on infants susceptible to disease.

\section{References}

1. K. Aditi, Social and Intergenerational Determinants of Children's Physical and Cognitive Development. Doctoral Dissertation, Harvard T.H. Chan School of Public Health (2015)

2. Balitbangkes, Pokok-Pokok Hasil Riskesdas (2013)

3. J.R. Behrman, M.R. Rosenzweig, Am. Econ. Rev. 92, 1, 323-34 (2002)

4. R.E. Black, et al., Lancet 371, 243-260 (2008).

5. R.E. Black, S.S. Morris, J. Bryce, Lancet 361, 2226-2234 (2003)

6. A. Case, D. Lubotsky, C. Paxson, Economic status and health in childhood (2002)

7. G.J. Duncan, A. Kalil, K. Ziol-Guest, Maternal Age and Child Achievement (Princeton University, 2015)

8. K. Eka, Faktor Risiko Kejadian Stunting Pada Anak Usia 2-3 Tahun (Studi Kecamatan Semarang Timur) (Universitas Diponegoro, Semarang, 2015)

9. J.M. Gardner, S. Grantham-McGregor, J. Himes, S. Chang, Journal of Child Psychology and Psychiatry 40, 5, 819-827 (1999)

10. P.D. Gluckman, M.A. Hanson, A.S. Beedle, A.S., Am. J. Hum. Biol. 19, 1e19 (2007)

11. S.M. Grantham-McGregor, Y.B. Cheung, S. Cueto, P. Glewwe, L. Richter, B. Strupp, et al., Lancet 369, 60-70 (2007)

12. J. Hoddinot, H. Alderman $\mathrm{H}$, et al., The economic rationale for investing in stunting reduction (2013)

13. G. Hutton, Haller, Evaluation of the Cost and Benefits of Water and Sanittaion Improvements at the Global Level (World Health Organization, 2004)

14. R. Martorell, B.L. Horta, L.S. Adair, A.D. Stein, L. Richter, C.H. Fall, et al., J. Nutr. 140, 348-354 (2010)

15. Martorell, Young, Patterns of Stunting and Wasting: Potensial Explanatory Factors (2012)

16. E. Ozaltin, K. Hill, S.V. Subramanian, JAMA 303, 1507-1516 (2010)

17. A.B.R. Pruss-ustun, F. Gore, J. Bartram, SaferWater, Better Health: Costs, Benefits and Sustainability of Interventions to Protect and Promote Health (WHO, Geneva, 2008) 
18. U. Ramakrishnan, R. Martorell, D.G. Schroeder, R.J. Flores, Nutr. 129, 544S-549S (1999)

19. Ramli, et al., BMC Pediatrics 9, 64 (2009)

20. D. Spears, How Much International Variation in Child Height can Sanitation Explain? World Bank Policy Research Working Paper 635 (2013)

21. Task Manager, Sustainable Development Division, United Nations Dept of Economic and Social Affairs, Interagency Task Force on Gender and Water (GWTF) Report of activities (2005-2006)

22. H. Torlesse et al., Determinant of Stunting in Indonesian Children: Evidance from a Cross-Sectional Survey Indicate a Prominent Role for The Water, Snitation and Hygiene Sector in Stunting Reduction (2016)

23. C.G. Victora, L. Adair, C. Fall, et al., Lancet 371, 340-57 (2008)

24. S. Vyas, P. Kov et al., Disease and Net Nutrition : Evidence Vhanges in Sanitation, and Child Height in Cambodia, 2005-2010 (2016)

25. WHO, World Health Organ. Tech. Rep. Ser. 854, 1-452 (1995)

26. WHO/UNICEF, Progress on Drinking Water and Sanitation (2014)

27. World Bank, Water Supply and Sanitationin Indonesia Turning Finance into Service for the Future. Service Delivery Assessment (2015) 